In August 2012 newspapers reported a tiger killing cattle in farmland and state forests outside the eastern boundary of Nagarahole Tiger Reserve in Karnataka. On 25 August the tiger attacked a woman who was grazing livestock in the vicinity, and partially consumed her. On 26 August Forest Department staff located the tiger, using domestic elephants, and tranquillized and captured it.

Using an extensive photo-database of individual tigers camera-trapped in Karnataka over the past 2 decades, Wildlife Conservation Society (WCS)-India scientists identified the captured man-eater as tiger NHT-222. This adult male was first camera-trapped on 6 May 2005, when he was 3-4 years old, in the Metikuppe Range of Nagarahole Tiger Reserve. He was subsequently camera trapped several times over 6 years and the last photo capture was on 26 December 2011 during annual camera-trap surveys carried out in collaboration with the Karnataka State Forest Department and the National Tiger Conservation Authority.

Prior to this incident the tiger had been sighted by Forest Department staff in the last week of May 2012, injured, near a waterhole in the Sunkadakatte area. It appears that the tiger, estimated to be 10-12 years old, did not recover from his injuries and was pushed to the fringe of the Reserve, where he may have resorted to whatever prey he found, including livestock, and, unfortunately, a human being. Upon tranquillization it was discovered that the tiger had a serious injury in its right forepaw and that his canines were worn out and broken. This prompted the Karnataka Forest Department to house him in Mysore Zoo. This incident highlights the value of long-term scientific data in facilitating management decisions.

Although the fate of such individual tigers attracts much sympathetic press, this misses the point: NHT-222 is a part of a process of natural loss. Nagarahole has a healthy tiger density of 10-12 individuals per $100 \mathrm{~km}^{2}$. WCS-India's longterm studies show that mortality and dispersal cause on average a $22 \%$ annual loss to tiger populations. A stable and breeding tiger population compensates for such annual losses. In relatively secure habitats such as Nagarahole, which is rich in prey, resident females are able to rear successive litters of cubs.

N. SAMBA KUMAR and PRERNA SINGH BINDRA Wildlife Conservation Society-India Program, Bangalore, India

E-mailsamba.wcs@gmail.com

\section{Tourism turf wars: debating the benefits and costs of wildlife tourism in India}

Wildlife tourism in India, especially tiger-centric tourism, has been reined in by the country's Supreme Court because the industry was becoming increasingly unsustainable and over-exploitative. On 24 July 2012, in an interim order, the Supreme Court conditionally banned tourism in the core or critical tiger habitats of all 41 tiger reserves in India in response to a Public Interest Litigation filed by activist Ajay Dubey in September 2010. In the order the Court also asked states to notify buffers for tiger reserves as mandated by law. The purpose behind the Court's temporary ban appeared to be to force states to notify buffer zones for tiger reserves and establish standards of allowable growth and best practices for tourism. The temporary ban fuelled an ongoing, acrimonious and polarized debate on whether tourism is harming or benefiting wildlife in India, and if its benefits reach local communities or the reserves. Much of the furore appears to be centered on popular tiger reserves such as Ranthambhore, Kanha and Corbett.

The debate was triggered by a report on the impacts of wildlife tourism in the popular Corbett Tiger Reserve. The report noted that ill-planned and unregulated tourism had damaged prime meadows and habitats and choked key tiger and elephant corridors. This debate must be viewed in the context that India is home to $50 \%$ of the world's surviving tiger populations. Although the country potentially has c. $250,000 \mathrm{~km}^{2}$ of tiger habitat only c. $10 \%$ of these populations, primarily those in protected wildlife reserves, are viable source populations with reasonable densities of tigers. Protecting these source populations requires concerted efforts to mitigate all threats. Although tourism is not the primary threat to tigers, unregulated and unplanned growth in tourism is intensifying pressure, especially around some reserves, and in its current form is unsustainable.

India's wildlife tourism is growing at $15 \%$ annually and tourist facilities use local resources heavily, especially water and fuelwood. Tourism has only marginally benefited local communities and the reserves themselves. Yet, this growth in tourism is also an opportunity to increase public support for tigers and wildlife conservation in India. Unfortunately, rather than focusing the discussion on how to regulate and improve existing tourism management and practices so that the public can continue to enjoy the opportunity to view wildlife, much of the debate has focused on defending high-end tiger tourism, which is restricted to a few reserves and is less relevant to the larger conservation context.

In response to the Court's directives the Ministry of Environment and Forests (MoEF) redrafted guidelines on tourism in tiger reserves, taking into consideration the views of all stakeholders. These guidelines-largely a framework for states to build their own ecotourism strategy-allows regulated, low-impact tourism in a maximum of $20 \%$ of the core or critical tiger habitat of a reserve. The new policy also seeks to encourage low-ecological footprint, budget tourism, and a flow of benefits to local communities and reserves and envisages a conservation cess to be paid by resorts. These guidelines prohibit the building of new infrastructure in core areas or in areas from which villages have been voluntarily relocated to recreate inviolate 
habitats. A major lacuna, however, is that the guidelines fail to adequately curb the construction boom on the fringes of reserves. The guidelines also evade other critical issues such as defining the 'zone of influence' around a reserve.

On 16 Oct 2012 the Supreme Court lifted the ban, allowing tourism to recommence in core areas in accordance with the MoEF guidelines However, whether these guidelines will be executed and implemented effectively depends on state and local authorities, and the process will be scrutinized by many in India.

PRERNA BINDRA Wildlife Conservation Society-India Program, Bangalore, India. E-mail prerna.wcsindia@gmail.com

KRITHI K. KaRANTH Centre for Wildlife Studies, Bengaluru, India, and Nicholas School of Environment, Duke University, Durham, North Carolina, USA

\section{First images of the Visayan spotted deer and Visayan warty pig}

The Greater Negros-Panay faunal region of the Philippines is known to harbour at least five large mammal species, two of which (the Visayan spotted deer Rusa alfredi and the Visayan warty pig Sus cebifrons) are found nowhere else. Habitat loss, alteration and fragmentation as a result of anthropogenic activities are a major problem in this region and, consequently, these endemic mammals are confined to forest fragments that cover only $7 \%$ of the original extent of this recognized biodiversity hotspot.

Fragmented populations of the Critically Endangered Visayan warty pig survive only on Negros, Panay and possibly Masbate, and are thought to number $<_{1,000}$ in total. The Endangered Visayan spotted deer is believed to be restricted to west Panay and a few scattered remnants of forest on Negros, and is thought to number no more than 2,500. Despite their ecological importance and relatively small geographical ranges the distribution of these two species have only been vaguely described, and systematic field surveys and monitoring are practically non-existent. Fieldwork has been hampered, in part, by the nocturnal and elusive behaviour of these animals and their preference for rugged slopes of dipterocarp forest that are typically inaccessible to humans. The availability of camera traps now facilitates monitoring for such species but this methodology had not previously been used specifically for the large mammal fauna of this region.

To gather information on the presence of large mammals a small team entered the interior of North Negros National Park in 2012. We conducted a camera trap survey during March-April 2012 using 20 cameras, which were each left in place for 9-11 days for a total of 185 camera-trap days. The survey produced a total of 1,455 photographs. In 1,357 photographs no animals were registered and two were of small birds. The remaining 86 photographs were of Asian palm civet, Philippine long-tailed macaque, Visayan spotted deer and Visayan warty pig. These were the first images of the Visayan spotted deer and the Visayan warty pig to be obtained in the wild. The survey demonstrates that camera trapping can provide reliable wildlife data with few personnel over a relatively short period of time in protected areas in the Philippines.

Previous biodiversity assessments on the edges of North Negros National Park have highlighted the anthropogenic threats of encroaching agriculture, illegal logging and hunting, all of which threaten the integrity of the Park. During our study we repeatedly came across evidence of illegal hunting activity throughout the Park, including within the forest interior. On several occasions we observed groups of hunters and encountered evidence of temporary camp sites. Discussions with local forestry staff and field guides from a local mountaineering society indicate that hunting activity is common, with individuals making forays into the Park on at least a monthly basis, and is increasing in frequency.

The evidence collected shows that immediate, increased conservation management action is required to protect the large mammal diversity of North Negros National Park. We urge the Philippine Department of Environment and Natural Resources and international and national nature conservation organizations to direct their attention to the this Park, which is of global importance because of its endemic, threatened large mammal fauna.

Based on the findings of this assessment we make the following recommendations: (1) enhanced management of North Negros National Park is required, with associated increased budgetary resource allocations; (2) increased monitoring and control of illegal captures of Visayan spotted deer and Visayan warty pig are required within the Park; and (3) the application of camera-trap monitoring for these species is required as this methodology addresses the logistical difficulties that have hampered previous efforts. These recommendations have been shared with the appropriate authorities, to help inform future conservation action focussed on these threatened large mammals.

Neil D'Cruze, James Sawyer and Ruth De Vere The World Society for the Protection of Animals, London, UK E-mailneildcruze@wspa-international.org

JAMES BeNARES Butlak Banaag Mountaineering Society, Negros Occidental, Philippines

DAVID FaRRANCE British Antarctic Survey Medical Unit, Derriford Hospital, Plymouth, UK 